Fourth International Conference on Sustainable Construction Materials and Technologies http://www.claisse.info/Proceedings.htm

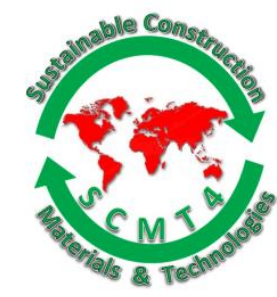

SCMT4

Las Vegas, USA, August 7-11, 2016

\title{
Strength Development and Shrinkage Cracking Resistance of High Alite Cement Concrete with Fly Ash
}

\author{
Shingo Miyazawa ${ }^{1 \mathrm{a},}$ Takashi Yokomuro ${ }^{1 \mathrm{~b}}$, Etsuo Sakai $^{2}$, Nobukazu Nito ${ }^{3}$, and \\ Hiroshi Hirao ${ }^{4}$
}

${ }^{1}$ Ashikaga Institute of Technology, 268-1 Ohmae, Ashigaka, 326-8558, JAPAN

${ }^{1 a}$ Email: 〈smiyazaw@ashitech.ac.jp>, ${ }^{1 b}$ Email:<yokomuro@ashitech.ac.jp>

${ }^{2}$ Tokyo Institute of Technology, 2-12-1 O-okayama, Meguro-ku, Tokyo, 152-8552 JAPAN

Email:<esakai@ceram.titech.ac.jp>

${ }^{3}$ DC Co., Ltd., 8 Higashida, Kawasaki-ku, Kawasaki, 210-0005, JAPAN

Email:<nito_nobukazu@dccorp.jp>

${ }^{4}$ Taiheiyo Cement Corporation, 2-4-2 Osaku, Sakura, 285-8655 JAPAN

Email:<Hirao@taiheiyo-cement.co.jp>.

\begin{abstract}
In order to reduce $\mathrm{CO}_{2}$ emission in the process of cement production, it is efficient to use blended cement, such as blast-furnace slag cement and fly ash (FA) cement, widely for concrete structures instead of ordinary Portland cement. However, in Japan, FA cement has rarely been used for concrete structures, since strength development of concrete with FA cement is relatively slow at early ages. The purpose of this study is to propose FA cement which can be widely used for general concrete structures. In this study, cement samples with alite contents increased up to $72 \%$, by Bogue equation, were manufactured on trial at an actual cement plant and strength development of FA cement concrete using the high alite cement was experimentally investigated. Tendency of shrinkage cracking in concrete under drying condition was also investigated with uniaxial restraint tests, in which restraint stress and drying period until cracking were observed. It was shown by the test results that early-age strength development of FA cement concrete could be improved by using the high alite cement, especially at low temperatures. It was suggested that shrinkage cracking resistance of concrete with the proposed FA cement could be higher than with ordinary Portland cement.
\end{abstract}

\section{INTRODUCTION}

During the production of ordinary Portland cement (OPC), large amount of $\mathrm{CO}_{2}$, which is thought to be a main cause of global warming, is emitted into the air, since limestone $\left(\mathrm{CaCO}_{3}\right)$ decarbonates through the process of clinker production. On the other hand, blended cements such as blast-furnace slag (BFS) cement and fly ash (FA) cement give off less amount of $\mathrm{CO}_{2}$ than OPC. Therefore, blended cement has been widely used from environmental point of view in many countries.

In Japan, conventional blended cements are generally produced by blending FA or BFS with OPC, whose $\mathrm{C}_{3} \mathrm{~S}$ content ranges typically from $55 \%$ to $60 \%$. Although BFS cement has often been applied to civil 
engineering structures, FA cement has rarely been used for concrete structures except for dam concrete. Furthermore, the consumption of FA cement accounts for no more than $0.1 \%$ of the total cement consumption, while the consumption of OPC accounts for about $70 \%$. It should be also pointed out that the addition of BFS or FA at concrete mixing plants is very rare in this country because of insufficient facilities in concrete mixing plants and delivery systems. Therefore, it is expected that FA cement is extensively used for concrete structures to reduce $\mathrm{CO}_{2}$ emission in cement industry.

In order to increase application of FA cement to general concrete structures, it is desirable to improve earlyage strength development of concrete. Several measures to accelerate strength development of FA cement have been suggested in published papers. It was reported from experimental study that fine particles in FA made higher contribution toward strength development than coarse particles [Erdoğdu and Türker 1998]. It was also reported that strength development of FA cement mortar was accelerated at early ages by replacing a part of FA by limestone powder [Weerdt et al. 2011].

There are some researches on the effect of mineral composition of clinker on strength development of blended cement. It was reported that early-age compressive strength of FA cement concrete could be improved by using high-early strength Portland cement with $\mathrm{C}_{3} \mathrm{~S}$ content of $65 \%$ [Morioka et al. 2002]. It was also reported that clinkers with $\mathrm{C}_{3} \mathrm{~S}$ content up to $73 \%$ prepared in a laboratory could be effectively used for FA cement with a high replacement ratio [Hou et al. 2007]. However, these studies have not been applied to practical uses. The authors reported that clinkers with very high $\mathrm{C}_{3} \mathrm{~S}$ content up to $71 \%$, by Bogue equation, were manufactured at an actual cement plant [Nito et al. 2014], and that strength development of BFS cement could be improved by using the high $\mathrm{C}_{3} \mathrm{~S}$ clinker [Miyazawa et al. 2014].

The purpose of this study is to propose FA cement which can be widely used not only for civil engineering concrete structures but also reinforced concrete buildings. In order to improve strength development of FA cement at early ages, some samples of clinker with very high $\mathrm{C}_{3} \mathrm{~S}$ content about $70 \%$, by Bogue equation, were manufactured at an actual cement plant. Replacement ratio of FA was taken to be $15 \%$ or $20 \%$, and the effect of the contents free $\mathrm{CaO}$ and $\mathrm{SO}_{3}$ of FA cement were investigated. Strength development of concrete with FA cement using the high $\mathrm{C}_{3} \mathrm{~S}$ clinkers was experimentally investigated, taking account of the effect of curing temperature. Tendency of cracking of concrete due to dying shrinkage was also investigated with uniaxial restraint tests.

\section{EXPERIMENTAL PROCEDURES}

\section{Materials}

The samples of high alite cement $\mathrm{A}_{1}$ and $\mathrm{A}_{2}$ were produced at an actual cement plant, which has been used for production of OPC for commercial use. Chemical compositions and mineral composition of materials used in the experiments are shown in Table 1 and Table 2, in which mineral compositions of the cement samples are calculated with Bogue equations. Samples of cement $A_{1}$ and $A_{2}$, which were to be used as base cement for FA cement, have larger $\mathrm{C}_{3} \mathrm{~S}$ content and larger free $\mathrm{CaO}$ content than OPC. Blaine fineness of the samples of cement $\mathrm{A}_{1}$ and $\mathrm{A}_{2}$ is higher than OPC.

In general, OPC with free $\mathrm{CaO}$ content of less than $1 \%$ is used as base cement for FA cement. However, the optimum free $\mathrm{CaO}$ content as the base cement for FA cement has not been investigated. In this study, samples of cement $\mathrm{A}_{1}$ and $\mathrm{A}_{2}$ with relatively higher free $\mathrm{CaO}$ content were prepared. Cement $\mathrm{A}_{1}$ with free $\mathrm{CaO}$ content of $1.8 \%$ was used in Series I and Series II, and cement $\mathrm{A}_{2}$ with free $\mathrm{CaO}$ content of $3.0 \%$ was used in series III. For the FA cement samples in Series II and III, anhydrous gypsum was added at mixing concrete in amount such that $\mathrm{SO}_{3}$ content of FA cement was $2.9 \%$ and $3.4 \%$, respectively. In Series I, on the other hand, additional anhydrous gypsum was not added at mixing concrete. 
Samples of $F A\left(F_{1}\right.$ and $\left.F_{2}\right)$ used in this study are by-products from two different coal-fired power plants. Their properties, which are shown in Table 1 and Table 3, agree with the requirements of Class II fly ash specified by JIS A 6201 [Japanese Standards Association 2012]. Class II fly ash, which corresponds to

Table 1. Chemical Composition of Cements and Fly Ash

\begin{tabular}{|c|c|c|c|c|c|c|c|c|c|c|c|}
\hline \multirow[t]{2}{*}{ Cement } & \multirow{2}{*}{$\begin{array}{c}\text { Serie } \\
\mathrm{s}\end{array}$} & \multicolumn{10}{|c|}{ Chemical composition of cement (\%) } \\
\hline & & $\begin{array}{l}\text { ig- } \\
\text { loss }\end{array}$ & $\mathrm{SiO}_{2}$ & $\mathrm{Al}_{2} \mathrm{O}_{3}$ & $\mathrm{Fe}_{2} \mathrm{O}_{3}$ & $\mathrm{CaO}$ & $\mathrm{MgO}$ & $\mathrm{SO}_{3}$ & $\begin{array}{c}\mathrm{Na}_{2} \\
\mathrm{O}\end{array}$ & $\mathrm{K}_{2} \mathrm{O}$ & $\begin{array}{c}\text { f.Ca } \\
\mathrm{O}\end{array}$ \\
\hline $\mathrm{A}_{1}$ & $\mathrm{I}, \mathrm{II}$ & 0.90 & 19.8 & 5.39 & 2.87 & 65.6 & 1.64 & 2.43 & 0.31 & 0.35 & 1.8 \\
\hline$\overline{A_{2}}$ & III & 1.29 & 18.8 & 5.30 & 2.77 & 64.8 & 2.12 & 3.36 & 0.41 & 0.40 & 3.0 \\
\hline $\mathrm{N}_{1}$ & I, II & 0.87 & 21.0 & 5.86 & 3.08 & 63.2 & 2.08 & 2.39 & 0.45 & 0.38 & 0.8 \\
\hline $\mathrm{N}_{2}$ & III & 1.09 & 20.7 & 5.33 & 3.11 & 64.0 & 2.01 & 2.24 & 0.44 & 0.34 & 0.6 \\
\hline $\mathrm{FA}_{1}$ & I, II & 2.04 & 59.2 & 25.4 & 5.31 & 2.86 & 1.21 & 0.46 & 0.62 & 1.40 & - \\
\hline $\mathrm{FA}_{2}$ & III & 1.10 & 58.5 & 27.6 & 4.60 & 3.10 & 1.1 & 0.20 & 1.10 & 0.85 & - \\
\hline $\mathrm{BB}$ & I & 1.26 & 26.0 & 9.26 & 1.77 & 53.6 & 3.84 & 2.24 & 0.33 & 0.29 & - \\
\hline
\end{tabular}

Table 2. Physical Properties and Mineral composition of Cements

\begin{tabular}{|c|c|c|c|c|c|c|c|}
\hline \multirow[t]{2}{*}{ Cement } & \multirow[t]{2}{*}{ Series } & \multirow{2}{*}{$\begin{array}{l}\text { Density } \\
\left(\mathrm{g} / \mathrm{cm}^{3}\right)\end{array}$} & \multirow{2}{*}{$\begin{array}{c}\text { Blaine } \\
\text { fineness } \\
\left(\mathrm{cm}^{2} / \mathrm{g}\right)\end{array}$} & \multicolumn{4}{|c|}{ Mineral composition (\%) } \\
\hline & & & & $\mathrm{C}_{3} \mathrm{~S}$ & $\mathrm{C}_{2} \mathrm{~S}$ & $\mathrm{C}_{3} \mathrm{~A}$ & $\mathrm{C}_{4} \mathrm{AF}$ \\
\hline$A_{1}$ & I, II & 3.15 & 4690 & 69 & 5 & 10 & 9 \\
\hline $\mathrm{A}_{2}$ & III & 3.10 & 4820 & 72 & 0 & 9 & 8 \\
\hline $\mathrm{N}_{1}$ & I, II & 3.16 & 3290 & $59^{*}$ & $14^{*}$ & $9^{*}$ & $10^{*}$ \\
\hline $\mathrm{N}_{2}$ & III & 3.16 & 3340 & 57 & 16 & 9 & 10 \\
\hline $\mathrm{BB}$ & I & 3.04 & 4080 & - & - & - & - \\
\hline
\end{tabular}

Table 3. Properties of Fly Ash (FA)

\begin{tabular}{|c|c|c|c|c|}
\hline \multicolumn{2}{|c|}{ Item } & $\mathrm{FA}_{1}$ & $\mathrm{FA}_{2}$ & JIS A 6201 \\
\hline \multicolumn{2}{|c|}{$\mathrm{SiO}_{2}, \%$} & 59.2 & 58.5 & $\geq 45.0$ \\
\hline \multicolumn{2}{|c|}{ Moisture content $\%$} & $<0.5^{*}$ & $0.1^{*}$ & $\leq 1.0$ \\
\hline \multicolumn{2}{|c|}{ Loss on ignition $\%$} & 2.04 & 1.1 & $\leq 5.0$ \\
\hline \multicolumn{2}{|c|}{ Density, $\mathrm{g} / \mathrm{cm}^{3}$} & 2.28 & $2.24^{*}$ & $\geq 1.95$ \\
\hline \multicolumn{5}{|c|}{ Fineness } \\
\hline \multicolumn{2}{|c|}{ Amount retained when wet-sieved on $45 \mu \mathrm{m}$ sieve, $\%$} & $12^{*}$ & $9^{*}$ & $\leq 40$ \\
\hline \multicolumn{2}{|c|}{ Blaine, $\mathrm{cm}^{2} / \mathrm{g}$} & 3510 & 3690 & $\geq 2500$ \\
\hline \multicolumn{2}{|c|}{ Flow, percent of control, \% } & $110^{+}$ & $112^{*}$ & $\geq 95$ \\
\hline \multirow{3}{*}{$\begin{array}{l}\text { Strength activity } \\
\text { index, } \%\end{array}$} & 7 days & $72^{*}$ & 74 & - \\
\hline & 28 days & $85^{*}$ & 84 & $\geq 80$ \\
\hline & 91 days & $103^{*}$ & 102 & $\geq 90$ \\
\hline
\end{tabular}

obtained from quality control data at the plant 
Class F fly ash specified by ASTM C618-05 [American Society of Testing and Materials 2005], is typical FA for concrete in Japan.

For comparison, conventional FA cement, in which $15 \%$ of $\mathrm{N}_{2}$ is replaced by $\mathrm{FA}_{2}$, was used in series III. Blast-furnace slag Portland cement type B (BB), which is widely used in Japan, was also used in series I. The base cement for BB was OPC and the replacement ratio of BFS was about $40 \%$.

The samples of cement $\mathrm{N}_{1}$ and $\mathrm{N}_{2}$, which fall into a category of OPC, were used for making control specimens. In series I and II, the cement $\mathrm{N}_{1}$ contains minor additional constituents up to $5 \%$, which is the maximum requirement specified by JIS R 5210 (Japanese Standards Association, 2009), and the mineral compositions in Table 2 are for the cement clinkers, excluding minor additional constituents. In Series III, the sample of cement $\mathrm{N}_{2}$ does not contain minor additional constituents.

Fine aggregate and coarse aggregate used to make concrete specimens were river sand and crushed hard sandstone respectively, and the result of sieve analysis of them are shown in Table 4. Air-entraining and water-reducing agent (ad), whose main ingredients are lignin-sulfonic acid compound and polycarboxylic acid, was used for all the mixtures. In addition, in order to obtain the target air content of concrete, two types of air-entraining agents were used. Alkylcarboxylic acid type agent was used for concretes with FA and alkylether type agent was used for concrete without FA.

\section{Mix proportion of concrete}

The mix proportions of concrete prepared for the experiments are shown in Table 5. Water to cement ratio of concretes was fixed at 0.55 . Slump was $19 \pm 2.5 \mathrm{~cm}$ and air content was $5.0 \pm 1.5 \%$. The content of air-entraining and water-reducing agent (ad) was taken to be $1.0 \%$ for all the mix proportions.

Table 4. Results of Sieve Analysis of Aggregates

\begin{tabular}{|l|l|r|r|r|r|r|r|r|r|r|r|}
\hline Sieve size $(\mathrm{mm})$ & & 25 & 20 & 15 & 10 & 5 & 2.5 & 1.2 & 0.6 & 0.3 & 0.15 \\
\hline $\begin{array}{l}\text { Cumulative percentage } \\
\text { passing }(\%)\end{array}$ & Coarse aggregate & 100 & 96 & 74 & 23 & 0 & 0 & & & & \\
\cline { 2 - 10 } & Fine aggregate & & & & & 100 & 89 & 63 & 39 & 19 & 6 \\
\hline
\end{tabular}

Table 5. Mix Proportions of Concrete

\begin{tabular}{|c|c|c|c|c|c|c|c|c|c|}
\hline \multirow[t]{2}{*}{ Series } & \multirow[t]{2}{*}{ Cement } & \multirow[t]{2}{*}{$\mathrm{W} /(\mathrm{C}+\mathrm{FA})$} & \multirow{2}{*}{$\begin{array}{l}\text { s/a } \\
(\%)\end{array}$} & \multicolumn{5}{|c|}{ Unit content $\left(\mathrm{kg} / \mathrm{m}^{3}\right)$} & \multirow{2}{*}{$\begin{array}{c}\text { Ad } \\
\times(\mathrm{C}+\mathrm{FA}) \\
\%\end{array}$} \\
\hline & & & & $\mathrm{W}$ & $\mathrm{C}$ & FA & $\mathrm{S}$ & G & \\
\hline \multirow[t]{3}{*}{ I } & $\mathrm{A}_{1}-\mathrm{FA}_{1} 20(2.0)$ & 0.55 & 46.0 & 180 & 262 & 65 & 802 & 945 & 1.0 \\
\hline & $\mathrm{N}_{1}$ & & & 180 & 327 & - & 812 & 957 & 1.0 \\
\hline & BB & & & 175 & 318 & - & 817 & 963 & 1.0 \\
\hline \multirow[t]{2}{*}{ II } & $\mathrm{A}_{1}-\mathrm{FA}_{1} 20(2.9)$ & 0.55 & 46.0 & 180 & 262 & 65 & 802 & 945 & 1.0 \\
\hline & $\mathrm{N}_{1}$ & & & 180 & 327 & - & 812 & 957 & 1.0 \\
\hline \multirow[t]{3}{*}{ III } & $\mathrm{A}_{2}-\mathrm{FA}_{2} 15(3.4)$ & 0.55 & 46.0 & 180 & 278 & 49 & 802 & 946 & 1.0 \\
\hline & $\mathrm{N}_{2}-\mathrm{FA}_{2} 15(3.4)$ & & & 175 & 271 & 48 & 814 & 960 & 1.0 \\
\hline & $\mathrm{N}_{2}$ & & & 180 & 327 & 0 & 812 & 957 & 1.0 \\
\hline
\end{tabular}

ad : air-entraining and water-reducing agent 
Test methods. The specimens for measurements of compressive strength were cylinders with $100 \mathrm{~mm}$ in diameter and $200 \mathrm{~mm}$ in length. Strength development of concrete under standard curing was measured up to 91 days and early-age strength development of concrete under sealed curing was measured up to 7 days. In case of standard curing, concrete was casted at $20 \pm 2{ }^{\circ} \mathrm{C}$ and the specimens were cured under water at $20{ }^{\circ} \mathrm{C}$ until measurements of compressive strength at the ages of 3, 7, 28 and 91 days. In case of sealed cuing, the top surface of specimens was sealed immediately after casting in order to prevent evaporation and the specimens were stored in rooms at $20 \pm 1{ }^{\circ} \mathrm{C}$ and $10 \pm 1{ }^{\circ} \mathrm{C}$ until measurements of compressive strength at the ages of 1,2,3,5 and 7 days. Three specimens were prepared for each mixture and for each curing condition.

In order to study resistance to shrinkage cracking, restraint stress of concrete caused by drying shrinkage was measured by uniaxial restraint tests as shown in Figure 1. A deformed reinforcing bar with nominal diameter of $25 \mathrm{~mm}$ was embedded at the center of concrete beam specimens of $100 \mathrm{~mm}$ in width and depth and $1100 \mathrm{~mm}$ in length as a retraining body. Both the libs and lugs of the reinforcing bars were removed within the central portion with $300 \mathrm{~mm}$ in length and this portion was sealed with Teflon sheet with $0.2 \mathrm{~mm}$ in thickness in order to eliminate bond between reinforcing bar and concrete, as shown in Figure 1 (a). After casting, concrete specimens were cured in sealed condition until the age of 3 days and they were exposed to drying condition at $20 \pm 1{ }^{\circ} \mathrm{C}$ and $60 \pm 5 \%$ R.H. as shown in Figure 1 (b). Restraint stress of concrete caused by drying shrinkage was obtained from the strain of the embedded reinforcing bar which was measured with electric wire strain gauges attached on two opposite surfaces of the central portion of the reinforcing bar. During the drying period, the time at cracking in the specimens was detected from a sudden decrease in strain of the reinforcing bar. Three specimens were prepared for each mixture.

\section{RESULTS AND DISCUSSIONS}

\section{Environmental performance of cement}

In the manufacture process of the samples of high alite cement $A_{1}$ and $A_{2}$ in the actual cement plant, the

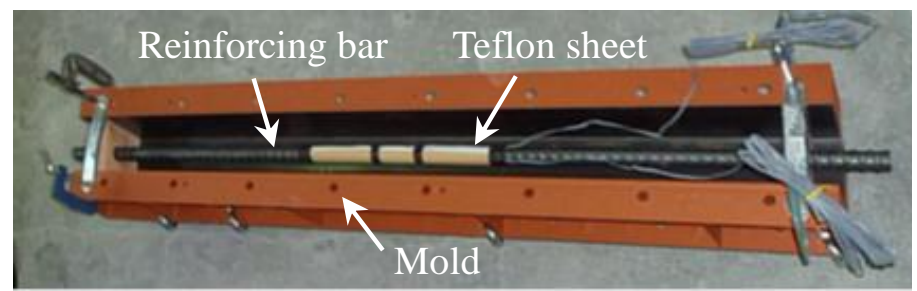

(a) Apparatus for restraint stress test

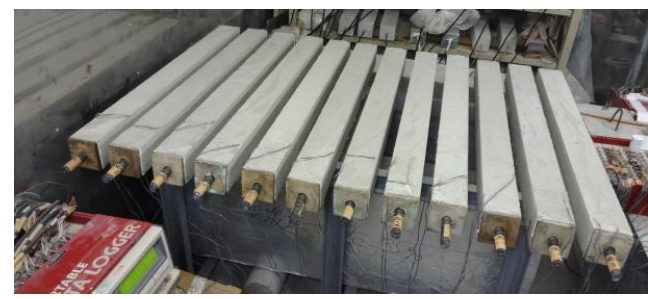

(b) Specimens stored in drying condition

\section{Figure 1. Test for Restraint Stress of Concrete due to Drying shrinkage}

kinds of raw materials for clinker including wastes and industrial by-products such as coal ash and construction generated soil were the same as those for OPC which had commercially been produced. From environmental point of view, the following points can be pointed out regarding to production of the clinker samples for $\mathrm{A}_{1}$ and $\mathrm{A}_{2}$.

(1) It can be said that the amount of limestone required for producing $A_{1}$ and $A_{2}$ clinkers are about the same as that for $\mathrm{N}_{1}$ and $\mathrm{N}_{2}$ clinkers, which can be clarified from the equivalent $\mathrm{CaO}$ contents in these clinkers (see Table 1). Therefore, $\mathrm{CO}_{2}$ emission due to decarbonation of limestone in the production of $\mathrm{A}_{1}$ and $\mathrm{A}_{2}$ clinkers is equivalent to OPC clinker. 
(2) Since the temperatures in the kiln during the calcination of $A_{1}$ and $A_{2}$ are about the same as $N_{1}$ and $N_{2}$, it can be said that $\mathrm{CO}_{2}$ emissions caused by calcination energy of $\mathrm{A}_{1}$ and $\mathrm{A}_{2}$ are equivalent to that of OPC.

(3) The consumption of electric power in the processes of law material treatment and grinding is about the same among $A_{1}, A_{2}, N_{1}$ and $N_{2}$. The reason why specific surface areas of $A_{1}$ and $A_{2}$ are higher than $N_{1}$ and $\mathrm{N}_{2}$ is that these clinkers contain larger amount of $\mathrm{C}_{3} \mathrm{~S}$ with high grindability.

Therefore, it can be said that $\mathrm{CO}_{2}$ emission due to the production of FA cement using the high alite cement is about the same as that of conventional FA cement at the same replacement ratio of FA. This means that $\mathrm{CO}_{2}$ emission of FA cement using the high alite cement is less than that of OPC without FA.

Compressive strength under water at $20^{\circ} \mathrm{C}$. In a published paper [Miyazawa et al. 2015], properties of FA cement using high alite cement with alite content of $69.3 \%$, belite content of $2.7 \%$ and free $\mathrm{CaO}$ content of $3.2 \%$ were studied, and the relation between replacement ratio of FA and compressive strength of concrete was given as shown in Figure 2. It can be seen from the results that compressive strength of concrete using high alite cement decreased with increase in replacement ratio of FA at 28 days or earlier. At 91 days, however, concrete with $10 \%$ FA gained higher strength than concrete without FA. Although compressive strength of high alite cement concrete without FA did not increase beyond the age of 28 days, compressive strength of concrete with FA increased even after 28 days, which may be due to pozzolanic reactivity of FA. When compared to OPC concrete without FA, compressive strength of high alite cement concrete up to 7 days was equivalent at FA replacement up to $20 \%$, but strengths at 28 days and 91 days are lower at FA replacement of more than $10 \%$. It is desirable that the replacement ratio of FA is more than around $15 \%$ in order to control alkali aggregate reaction. Therefore, the influence of chemical composition of clinker and replacement ratio of FA on strength development should be investigated.

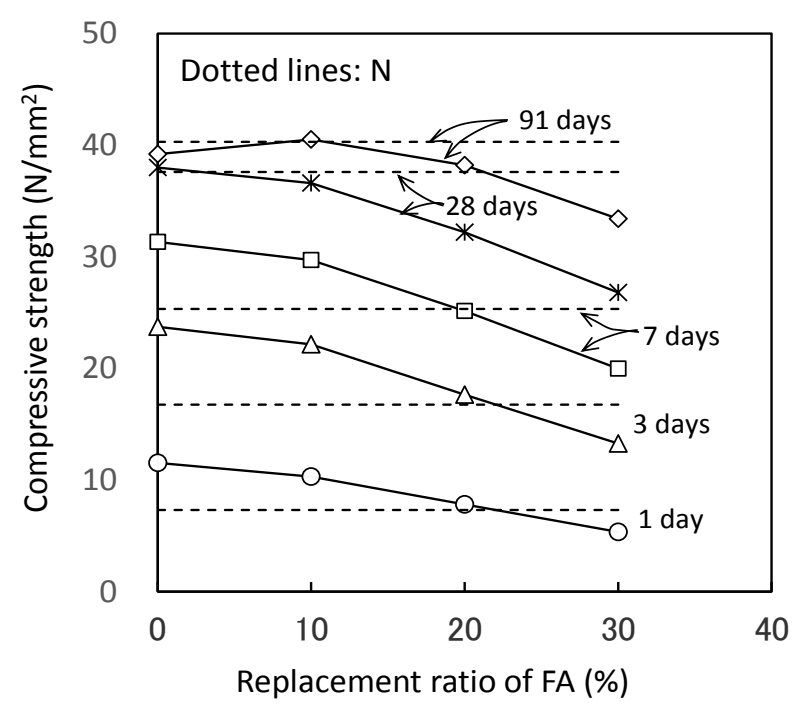

Figure 2. Compressive Strength of Concrete under Water at 20 oC

Table 6 shows compressive strength of concrete cured under water at $20^{\circ} \mathrm{C}$. It can be seen from this table that early-age strength of high alite cement concrete containing FA at $15 \%$ or $20 \%$ replacement ratios is more than those of OPC $\left(\mathrm{N}_{1}\right.$ and $\left.\mathrm{N}_{2}\right)$ and ordinary blended cement $\left(\mathrm{BB}\right.$ and $\left.\mathrm{N}_{2}-\mathrm{FA}_{2} 15\right)$. Furthermore, in series III, compressive strength of $\mathrm{A}_{2}-\mathrm{FA}_{2} 15(3.4)$ is equivalent to $\mathrm{N}_{2}$ even at 28 days and 91 days. The contents of $\mathrm{SO}_{3}$ and free $\mathrm{CaO}$ are different among series I, II and III, but the difference in strength development of high alite FA concretes is not so large. Belite content of $A_{1}$ is larger than that of $A_{2}$, but contribution to later-age strength development by belite is not clear. So, more studies should be conducted in the future. 
Table 6. Compressive Strength of Concrete Cured in Water at $20{ }^{\circ} \mathrm{C}$

\begin{tabular}{|c|c|c|c|c|c|}
\hline \multirow{2}{*}{ Series } & \multirow{2}{*}{ Cement } & \multicolumn{4}{|c|}{ Copmpressive strength $\mathrm{N} / \mathrm{mm}^{2}$ ) } \\
\cline { 3 - 5 } & & 3 days & 7 days & 28 days & 91 days \\
\hline I & $\mathrm{A}_{1}-\mathrm{FA}_{1} 20(2.0)$ & 18.8 & 25.7 & 33.2 & 38.5 \\
\hline & $\mathrm{N}_{1}$ & 18.3 & 26.4 & 35.1 & 38.9 \\
\hline & $\mathrm{BB}$ & 12.6 & 21.1 & 35.8 & 48.2 \\
\hline II & $\mathrm{A}_{1}-\mathrm{FA}_{1} 20(2.9)$ & 19.1 & 23.4 & 28.8 & 36.4 \\
\hline & $\mathrm{N}_{1}$ & 15.8 & 23.7 & 34.5 & 40.8 \\
\hline III & $\mathrm{A}_{2}-\mathrm{FA}_{2} 15(3.4)$ & 19.7 & 26.1 & 30.6 & 36.9 \\
\hline & $\mathrm{N}_{2}-\mathrm{FA}_{2} 15(3.4)$ & 13.5 & 19.1 & 27.4 & 38.4 \\
\hline & $\mathrm{N}_{2}$ & 16.2 & 23.9 & 30.9 & 36.9 \\
\hline
\end{tabular}

Compressive strength of sealed concrete at early ages cured at different temperatures. Test results for compressive strength of concrete at early ages up to 7 days, in which the specimens were cured in sealed condition at $10^{\circ} \mathrm{C}$ and $20^{\circ} \mathrm{C}$, are shown in Figurer 3. In this figure, the observed compressive strength is plotted against maturity calculated by equation (1), since compressive strength of concrete at various temperatures has often been estimated on the basis of maturity concept.

$$
M(t)=\sum_{z=1}^{t}\left(\theta_{z}+10\right)
$$

Where: $M(t)=$ maturity at age $t\left({ }^{\circ} \mathrm{C} \cdot\right.$ day $), \theta_{z}=$ the average temperature at age $z\left({ }^{\circ} \mathrm{C}\right)$ and $t, z=$ age of concrete (day).
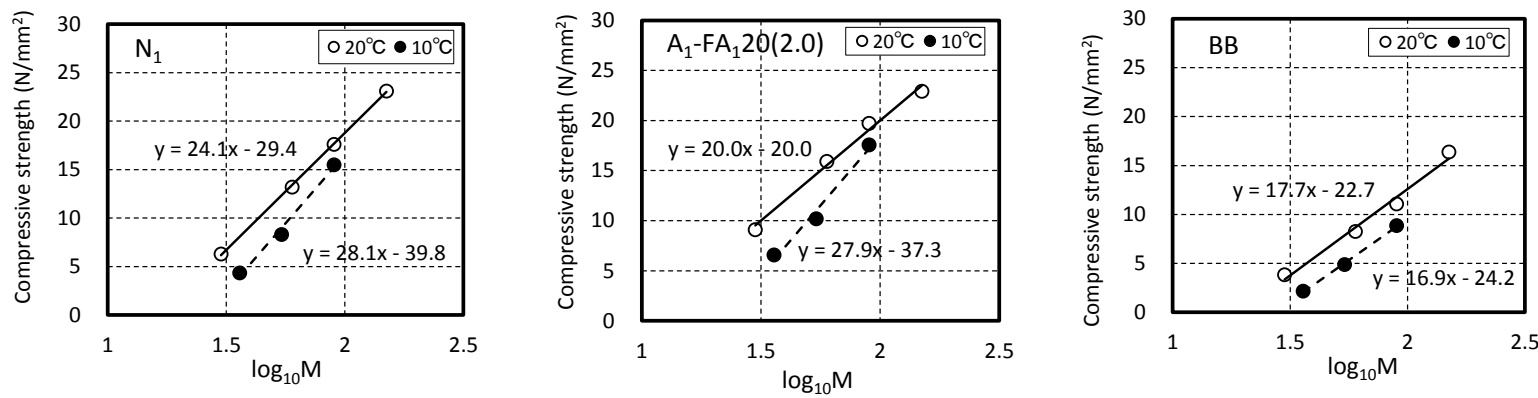

(a) Series I
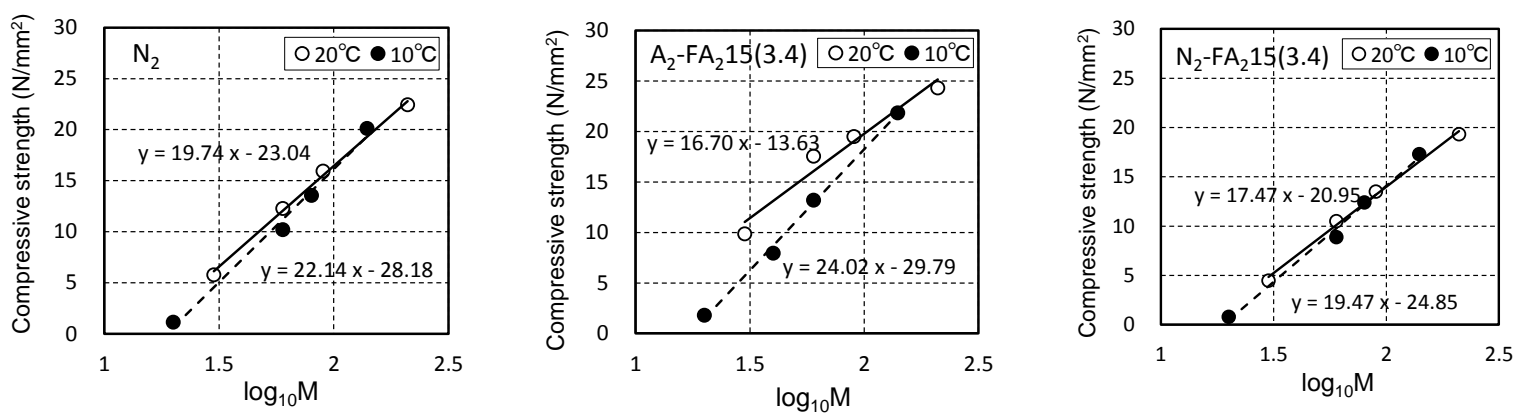

(b) Series III

Figure 3. Compressive Strength of Sealed Concrete 
When compared to the case of $20{ }^{\circ} \mathrm{C}$, development of compressive strength of concrete was delayed at 10 ${ }^{\circ} \mathrm{C}$ for any type of cement. However, compressive strength of concretes with $\mathrm{A}_{1}-\mathrm{FA}_{1} 20(2.0)$ and $\mathrm{A}_{2-}$ $\mathrm{FA}_{2} 15$ (3.4) increased earlier than those with $\mathrm{N}_{1}$ and $\mathrm{N}_{2}$ even if they were cured at $10{ }^{\circ} \mathrm{C}$. In Figure 3 , since linear relations can be seen between $\log _{10}(M)$ and compressive strength for each test condition, fitted lines were determined by regression analysis and are shown with the equations.

At construction sites, strength development of concrete is one of the useful indices to determine the form removal time which often affects the execution speed of construction projects. For example, it is specified by Architectural Institute of Japan that forms may be removed after confirming that concrete strength reaches the specified strength of 5 or $10 \mathrm{~N} / \mathrm{mm}^{2}$, depending on the service life of structures [Architectural Institute of Japan 2009]. The age at which compressive strength of concrete reaches $10 \mathrm{~N} / \mathrm{mm}^{2}$ was obtained from the fitted line for each type of cement in Figure 3, and it is shown in Table 7. It can be seen from this table that the age for conventional BFS cement (BB) and conventional FA cement $\mathrm{N}_{2}-\mathrm{FA}_{2} 15$ (3.4), at which compressive strength of $10 \mathrm{~N} / \mathrm{mm}^{2}$ is attained, is later than $\mathrm{N}_{2}$ and $\mathrm{N}_{2}$ at each temperature. Especially at 10 ${ }^{\circ} \mathrm{C}$, the age for $\mathrm{BB}$ is later than $\mathrm{N}_{1}$ by more than 2 days. For concretes with $\mathrm{A}_{1}-\mathrm{FA}_{1} 20(2.0)$ and $\mathrm{A}_{2}-$ $\mathrm{FA}_{2} 15(3.4)$, however, it is earlier than $\mathrm{N}_{1}$ and $\mathrm{N}_{2}$ by $0.3-0.7$ day at both temperatures. Therefore it can be said that some delay in form removal caused by using conventional blended cement can be avoided by using the high alite cement with FA.

\section{Shrinkage cracking resistance of concrete subjected to drying}

Restraint stress tests of concrete under dried condition were carried out in order to estimate resistance to shrinkage cracking of concrete with each type of cement. In this study, restraint stress of concrete subjected

Table 7. Age of Concrete to Obtain Compressive Strength of $10 \mathrm{~N} / \mathrm{mm}^{2}$

\begin{tabular}{|c|c|c|c|c|c|c|}
\hline \multirow{2}{*}{ Series } & Temperature & \multicolumn{5}{|c|}{ Age of concrete (days) } \\
\cline { 3 - 7 } & & $\mathrm{N}_{1}$ or $\mathrm{N}_{2}$ & $\mathrm{BB}$ & $\mathrm{N}_{2}-\mathrm{FA}_{2} 15(3.4)$ & $\mathrm{A}_{1}-\mathrm{FA}_{1} 20(2.0)$ & $\mathrm{A}_{2}-\mathrm{FA}_{2} 15(3.4)$ \\
\hline I & $20^{\circ} \mathrm{C}$ & 1.4 & 2.3 & - & 1.1 & - \\
\hline & $10^{\circ} \mathrm{C}$ & 3.0 & 5.3 & - & 2.5 & - \\
\hline III & $20^{\circ} \mathrm{C}$ & 1.6 & - & 2.0 & - & 0.9 \\
\hline & $10{ }^{\circ} \mathrm{C}$ & 2.7 & - & 3.1 & - & 2.3 \\
\hline
\end{tabular}

to drying at $20{ }^{\circ} \mathrm{C}, 60 \%$ R.H. after sealed curing for 3 days after casting. The test results were shown in Figure 4, in which tensile stresses are expressed as plus values on the vertical axis. It can be seen from this figure, that the restraint stresses increased with progressive drying and through cracks were observed in the specimens with sudden decreases in restraint stress in the most cases.

The period of drying until cracking in each specimen is shown in Table 8. It can be seen from these experimental results that the period of drying until cracking in $\mathrm{A}_{1}-\mathrm{FA}_{1} 20(2.0)$ concrete was slightly shorter than in $\mathrm{N}_{1}$ concrete and was slightly longer than in $\mathrm{BB}$ concrete. It can be seen that the period of drying until cracking increased as $\mathrm{SO}_{3}$ content was increased. In cases of $\mathrm{A}_{2}-\mathrm{FA}_{2} 15(3.4)$ and $\mathrm{N}_{2}-\mathrm{FA}_{2} 15$ (3.4), which have relatively large $\mathrm{SO}_{3}$ content of $3.4 \%$, the period of drying until cracking was much longer than that of $\mathrm{N}_{2}$. Therefore, it can be said that the resistance to shrinkage cracking of FA cement using high alite cement can be improved by increasing $\mathrm{SO}_{3}$ content up to $3.4 \%$. It should be noted that the restraint stress tests in this study were conducted in a single environmental condition and in a single degree of restraint. Therefore, the influences of the conditions on test results should be investigated in the future. 

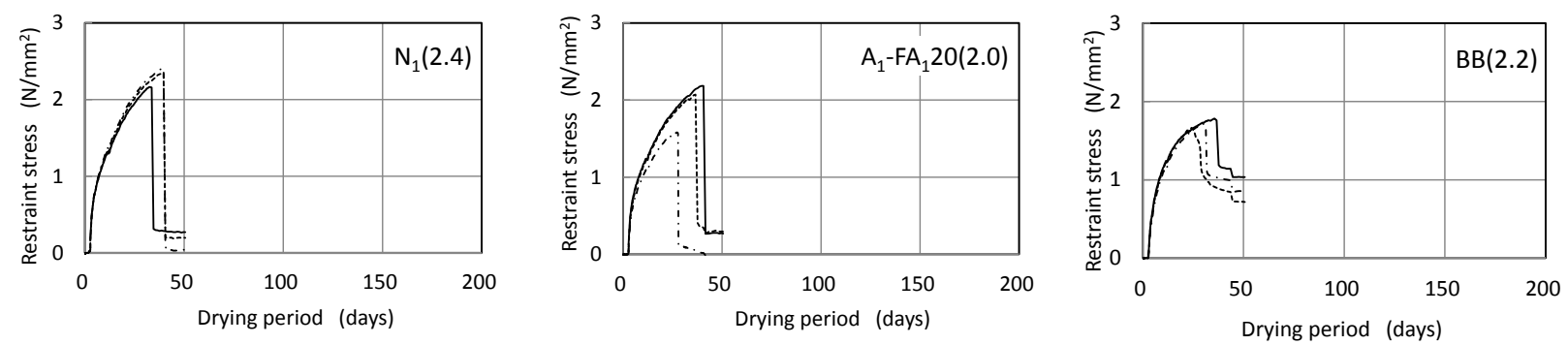

(a) Series I
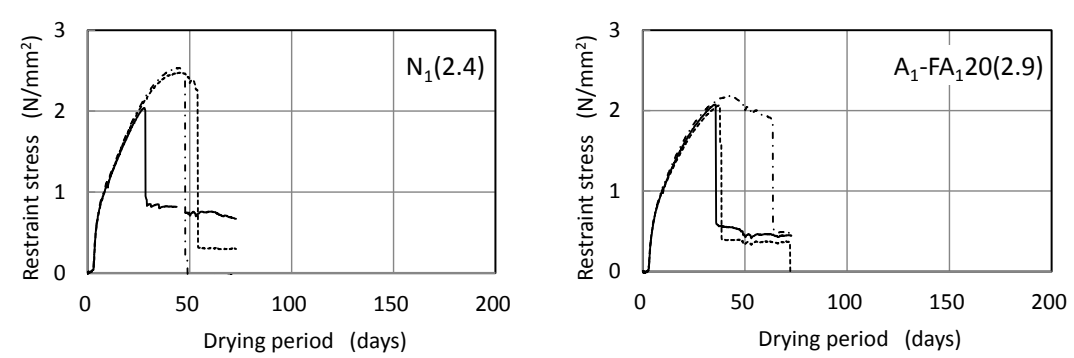

(b) Series II
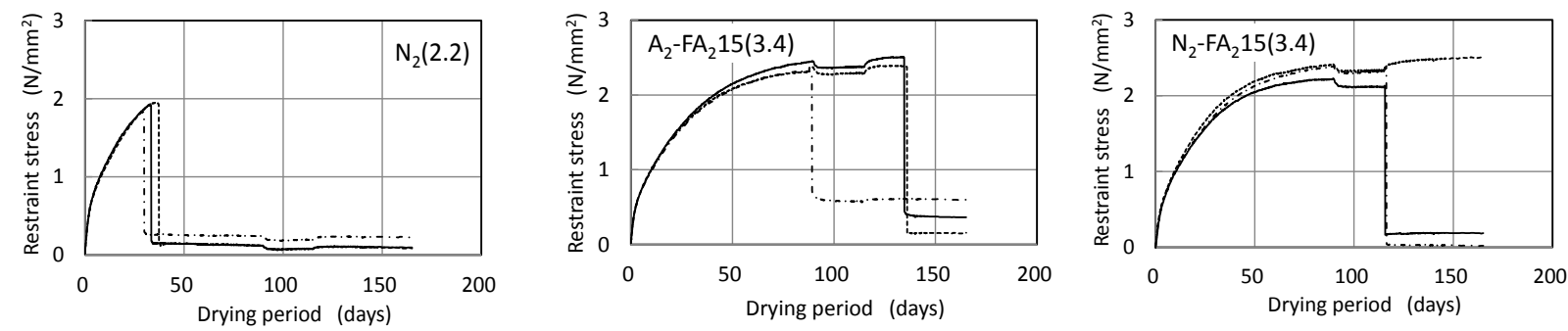

(c) Series III

Figure 4. Restraint Stress of Concrete

Table 8. Period of Drying until Cracking in concrete specimens

\begin{tabular}{|c|c|c|c|c|c|c|}
\hline \multirow{2}{*}{ Series } & \multirow{2}{*}{ Cement } & \multicolumn{4}{|c|}{ Period of drying until cracking (days) } & \multirow{2}{*}{ Rerated to $\mathrm{N}_{1} / \mathrm{N}_{2}$} \\
\hline & & No.1 & No.2 & No.3 & Average & \\
\hline \multirow[t]{3}{*}{ I } & $\mathrm{N}_{1}$ & 34 & 40 & 40 & 38.0 & - \\
\hline & $\mathrm{A}_{1}-\mathrm{FA}_{1} 20(2.0)$ & 28 & 37 & 41 & 35.3 & 0.93 \\
\hline & $\mathrm{BB}$ & 29 & 31 & 37 & 32.3 & 0.85 \\
\hline \multirow[t]{2}{*}{ II } & $\mathrm{N}_{1}$ & 28 & 48 & 54 & 43.5 & - \\
\hline & $\mathrm{A}_{1}-\mathrm{FA}_{1} 20(2.9)$ & 36 & 39 & 64 & 46.1 & 1.1 \\
\hline \multirow{3}{*}{ III } & $\mathrm{N}_{2}$ & 30 & 34 & 37 & 33.7 & - \\
\hline & $\mathrm{A}_{2}-\mathrm{FA}_{2} 15(3.4)$ & 89 & 136 & 138 & 121.0 & 3.6 \\
\hline & $\mathrm{N}_{2}-\mathrm{FA}_{2} 15(3.4)$ & 116 & 119 & $>165$ & $>117.5$ & $>3.5$ \\
\hline
\end{tabular}




\section{CONCLUSION}

The purpose of this study is to propose general-purpose FA cement, which can be widely used for concrete structures including reinforced concrete buildings. In the experiments, some clinker samples with high alite content were experimentally produced at an actual cement plant. Strength development and restraint stress due to drying shrinkage of concrete with FA cement using the high alite clinker were experimentally investigated in comparison with those of concrete with OPC or conventional blended cement.

- Cement clinker with alite content up to $72 \%$ by Bogue equation can be successfully produced at an actual cement plant.

- Compressive strength development of concrete with FA cement is significantly accelerated at early ages, when the high alite cement is used instead of OPC as the base material for FA cement.

- Experimental results suggest that the age of concrete at which the form removal is allowed can be set earlier for FA cement using the high alite clinker than for conventional FA cement or BFS cement.

- It is suggested from the restraint stress tests that the resistance to shrinkage cracking of concrete with FA cement using the high alite clinker can be improved by increasing $\mathrm{SO}_{3}$ content up to $3.4 \%$.

\section{ACKNOWLEDGEMENT}

The study presented in this paper was carried out as a part of the activity of "Technical Committee on General-Purpose Fly Ash Cement". The authors express sincere gratitude to the parties concerned.

\section{REFERENCES}

American Society of Testing and Materials, (2005). ASTM C618-05. "Standard specification for coal fly ash and raw or calcined natural pozzolan for use in concrete."

Architectural Institute of Japan, (2009). Japanese Architectural Standard Specification, JASS 5 Reinforced Concrete Work.

Erdoğdu K., Türker P., (1998). "Effects of fly ash particle size on strength of portland cement fly ash mortars." Cement and Concrete Research, Vol. 28, No. 9, 1217-1222.

Japanese Standards Association, (2009). JIS R 5210, "Portland cement."

Japanese Standards Association, (2012). JIS A 6201, "Fly ash for use in concrete."

Hou G., et al, (2007). "Composition design for high $\mathrm{C}_{3} \mathrm{~S}$ cement clinker and its mineral formation." Journal of Wuhan University of Technology, Materials Science Edition, Vol.22, No.1, 56-60.

Miyazawa S., et al, (2014). "Properties of concrete using high $\mathrm{C}_{3} \mathrm{~S}$ cement with ground granulated blastfurnace slag." Construction and Building Materials, Vol.61, 90-96.

Miyazawa S., et al, (2015). "Properties of concrete with fly ash cement using high $\mathrm{C}_{3} \mathrm{~S}$ clinker." The 14th International Congress on the Chemistry of Cement, CD-ROM.

Morioka M., et al, (2002). "Physical property and ecological evaluation of fly ash cement prepared from high-early strength cement and fly ash." Concrete Research and Technology, Vol.13, No.2, 33-39. [in Japanese]

Nito N., et al, (2014). "Experimental calcination of clinker with high $\mathrm{C}_{3} \mathrm{~S}$ content." Proceedings of the 68th Annual Meeting on Cement Technology, 32-33. [in Japanese]

Weerdt K. De, et al, (2011). "Hydration mechanisms of ternary Portland cements containing limestone powder and fly ash." Cement and Concrete Research, Vol. 41, 279-291. 